\title{
Prevalence of post-procedural pain and associated factors experienced after transradial coronary angiography
}

\author{
Murat Gula, Burak Acarb, Ozlem Karabulut', Mustafa Karanfilc, Sefa Unalc, \\ Cagri Yaylac, Ahmet Goktug Ertemc, Ilke Erbayc, Derya Tokc, Burcu Demirkanc, \\ Ayca Ozdemirc, Halil Lutfi Kisacikc
}

a Interventional Cardiology, Department of Cardiology, Aksaray University Education and Research Hospital, Aksaray, Turkey

${ }^{b}$ Interventional Cardiology, Department of Cardiology, Faculty of Medicine, Kocaeli University, Kocaeli, Turkey

' Interventional Cardiology, Department of Cardiology, Yuksek Ihtisas Education and Research Hospital, Ankara, Turkey

ARTICLE INFO

Article history:

Submitted: 29. 7. 2020

Revised: 25. 10. 2020

Accepted: 29. 10. 2020

Available online: 7. 7. 2021

\section{Klíčová slova:}

Bolest

Radiální

Koronarografie

\section{SOUHRN}

Úvod: V moderní kardiologické praxi představuje koronarografie základní diagnostický a terapeutický výkon. Díky svým mnoha přednostem se dnes místo femorálního přístupu používá převážně přístup radiální. Někteří pacienti si však po výkonu stěžují na bolest v oblasti radiální tepny. Starší studie se touto komplikací př́liš nezabývaly. Cílem naší studie bylo stanovit prevalenci bolesti v oblasti radiální tepny po koronarografickém vyšetření s radiálním přístupem a určit faktory ovlivňující míru bolesti po tomto výkonu.

Metody: Do této prưřezové studie bylo zařazeno celkem 100 po sobě následujících pacientů, u nichž bylo v období mezi lednem 2015 a lednem 2016 provedeno elektivní koronarografické vyšetření s radiálním přístupem \pm perkutánní koronární intervence. Po výkonu byli pacienti dotazováni na přítomnost obtěžujíci bolesti v předloktí, zvláště v oblasti zápěstí. Intenzita bolesti se hodnotila pomocí verbální stupnice. Pacienti byli rozděleni do skupin s časně pocitovanou bolestí (dvě hodiny po výkonu) a s dlouhodoběji pocitovanou bolestí (měsíc po výkonu); jejich údaje byly následně analyzovány.

Výsledky: Bolest v časné fázi (po dvou hodinách) uvedlo 55 pacientů, zatímco na dlouhodobější bolest ještě měsíc po výkonu s radiálním přístupem si stěžovalo 26 pacientů. Nezávislými prediktory bolesti byli muži operatéŕi $(\mathrm{OR}=3,386,95 \% \mathrm{Cl} 1,484-7,725 ; p=0,004)$ a zkušenosti operatéra $(\mathrm{OR}=4,147 ; 95 \% \mathrm{Cl} 1,637-$ $10,506 ; p=0,003)$. Na druhé straně nezávislými prediktory dlouhodoběji pocitované bolesti v oblasti radiální tepny byly nižší věk pacienta $(\mathrm{OR}=0,955 ; 95 \% \mathrm{Cl} 0,915-0,966 ; p=0,032)$ a zkušenosti operatéra $(\mathrm{OR}=3,947$; $95 \% \mathrm{Cl} 1,547-10,047 ; p=0,004)$.

Závěr: Bolest po koronarografickém vyšetření s radiálním přístupem není nijak výjimečná. Nezávislými prediktory bolesti po tomto výkonu jsou zkušenosti a pohlaví operatéra a věk pacienta.

(C) 2021, ČKS

\section{ABSTRACT}

Introduction: Coronary angiography is a principle diagnostic and therapeutic procedure in modern cardiology practice. The transradial access for cardiac catheterization has overtaken the transfemoral approach because of many advantages. However, some patients suffer radial pain after the procedure. Unfortunately, this complication has been poorly evaluated in previous studies. The present study aimed to determine the prevalence of radial pain after transradial coronary angiography and investigate factors that influence post-procedural pain. Methods: This is a cross-sectional study in which a total of 100 consecutive patients who underwent elective transradial coronary angiography \pm percutaneous coronary intervention between January 2015-2016 were evaluated. The patients were asked about presence of disturbing pain in the forearm especially wrist region after the procedure. Verbal rating scale was used to evaluate pain assessment. The patients were divided as early pain group (two hours after the procedure) and prolonged pain group (one month after the procedure) and analysis was performed.

Results: A total of 55 patients suffered from pain in the early phase (after two hours), and 26 of patients had prolonged pain at one month after the radial intervention. Independent pain predictors in the early pain group were male operator $(p=0.004, \mathrm{OR}=3.386,95 \% \mathrm{Cl}: 1.484-7.725)$ and experience of operator ( $\mathrm{OR}=$ $4.147,95 \% \mathrm{Cl}: 1.637-10.506, p=0.003)$. On the other hand, the younger age of patients $(\mathrm{OR}=0.955,95 \% \mathrm{Cl}$ : $0.915-0.966, p=0.032$ ) and experience of operator ( $\mathrm{OR}=3.947,95 \% \mathrm{Cl}: 1.547-10.047, p=0.004$ ) were the independent predictors of prolonged radial pain.

Conclusion: Pain after radial coronary angiography is not uncommon. Experience, operator gender, and age of the patients were independent predictors of pain after transradial coronary angiography.
Keywords:

Pain

Radial

Address: Murat Gul, MD, Interventional Cardiology, Department of Cardiology, Aksaray University Education and Research Hospital, 68100 Aksaray, Turkey, e-mail: drmuratgul68@gmail.com DOI: 10.33678/cor.2020.099 


\section{Introduction}

Coronary angiography is a principle diagnostic and therapeutic procedure in modern cardiology practice. The transradial access for cardiac catheterization has overtaken the transfemoral approach because of many advantages. Among those there are a rare incidence of access site-related complications, early mobilization, and shorter hospital stay. ${ }^{1-3}$ Recent evidence showed that transradial coronary angiography (TRCA) was related to fewer vascular complications ${ }^{4}$ and a favorable effect on outcomes, at least in some clinical settings. 5,6

Pain control is a major encountered challenge during and after invasive procedures. ${ }^{7}$ Its prevention is usually achieved by local subcutaneous infiltration of anesthetic substances. ${ }^{8}$ However, pain during the procedure is still a common issue for TRCA. It has been investigated mainly concerning the use of various anesthetic techniques and radial artery spasm ${ }^{9-11}$ or anatomy variance..$^{12}$

In our clinical practice, we encounter prolonged radial pain even in the absence of radial spasm, occlusion, and any other complications during the procedure. In some patients, this pain may be prolonged as long as one month. This study aimed to determine the prevalence of radial pain after TRCA in our local population; to investigate factors that influence post-procedural pain.

\section{Methods}

\section{Study population}

This is a cross-sectional study in which a total of 100 consecutive patients who underwent elective transradial coronary angiography \pm percutaneous coronary intervention (PCI) between January 2015-2016 were evaluated. Patients with previous transradial coronary revascularization, acute coronary syndrome, hemodynamic compromise, uncontrolled hypertension, vasculopathy, inability to tolerate nitroglycerin, or lidocaine due to allergy or medication interactions and radial spasm during catheterization were excluded from the study. Hypertension was defined as documented systolic blood pressure of $\geq 140 \mathrm{mmHg}$ and/ or diastolic blood pressure of $\geq 90 \mathrm{mmHg}$ in at least two measurements or active use of any antihypertensive agent. Diabetes was diagnosed as fasting plasma glucose over 126 $\mathrm{mg} / \mathrm{dl}$ or active use of an antidiabetic agent. Patients' weight and height were recorded and body mass index (BMI) was calculated as weight in $\mathrm{kg}$ divided by the square of height in meters. The study complied with the principles of the Declaration of Helsinki and was approved by the local ethics committee. The written informed consent was taken from all patients before the procedure. Operators with at least 300 radial interventions by the time of operation were considered an experienced operator.

\section{Cardiac catheterization}

All operators in our institution use the radial approach as their default access route. Before angiography, the Allen test was performed to determine the feasibility of the procedure for all patients. After subcutaneous local anesthesia with prilocaine (Citanest, AstraZeneca), cannulation of the radial artery was carried out with $6 \mathrm{~F}$ hydrophilic coated 7-cm sheath (Primelife transradial set; Copper Medical Technology Co Ltd, Shenzhen, China). Following the sheath insertion, $200 \mathrm{mg}$ nitroglycerin and $5000 \mathrm{IU}$ heparin were administered. Six French diagnostic coronary catheters (Boston Scientific, Maple Grove, MN, USA) were used for radial coronary angiography in our clinic. Routine premedication with agents such as midazolam or diazepam was not used in the study. To exclude the radial artery spasm or any other complications, we performed radial angiography after the procedure in the same line.

\section{Pain assessment and radial hemostasis}

Following the completion of the radial coronary angiography, radial sheaths were removed and local compression was applied with a gauze pad bandage. After 1 hour of sheath removal, the bandage was relaxed and kept on for two hours. The patients were discharged on the same day when the achievement of patent hemostasis and the patients who underwent $\mathrm{PCl}$ were discharged the following day. All patients' radial pulse was evaluated by palpation; if radial pulse absent, faint or the patient suffered severe pain duplex ultrasonography was performed to assess radial artery patency.

Post-procedural pain in the forearm, arm, or wrist area was evaluated using the verbal rating scale (VRS) two hours and one month after the intervention. Patients with puncture site pain were not included in the study. The VRS scale is a measure of pain intensity consisting of five numerically ordered words, including none-mildmoderate-severe-unbearable. ${ }^{13}$ Patients were called or interviewed face-to-face for a one-month evaluation.

\section{Statistical analysis}

All statistical analyses were performed in SPSS 20.0 Statistical Package Program for Windows (SPSS Inc., IL, USA). The normality of distributions of the parameters was assessed by the Kolmogorov-Smirnov test. Quantitative variables with a normal distribution were specified as the mean + standard deviation and those with non-normal distribution were specified with median (interquartile range); categorical variables were specified with number and percentage values. Continuous variables were compared using the independent samples t-test for normally distributed variables, and the Mann-Whitney $U$ test when the distribution was skewed. The chi-square test or Fisher's exact test was used to compare categorical variables.

Univariate logistic regression analysis was used to assess the relationship between variables and the presence of pain after coronary angiography. Variables found to be $p$ value of $<0.1$ in the univariate analysis were then used in forwarding stepwise multivariate logistic regression analysis to determine independent predictors of wrist and forearm pain. The results of the regression analyses were presented as odds ratios (OR) and $95 \%$ confidence intervals $(\mathrm{Cl})$. A $p$ value $<0.05$ was considered statistically significant.

\section{Results}

In total, 100 patients who underwent TRCA were enrolled in this study. There were 65 males and the mean age of 
Table 1 - Verbal rating scale of the patients according to the pain timing

\begin{tabular}{l|l|l}
\hline Verbal rating scale & $\begin{array}{l}\text { Early pain } \\
(\mathbf{n = 5 5 )}\end{array}$ & $\begin{array}{l}\text { Prolonged pain } \\
(\mathbf{n}=\mathbf{2 6})\end{array}$ \\
\hline Mild & $42(76 \%)$ & $19(73 \%)$ \\
\hline Moderate & $11(20 \%)$ & $6(23 \%)$ \\
\hline Severe & $2(4 \%)$ & $1(4 \%)$ \\
\hline Unbearable & 0 & 0 \\
\hline
\end{tabular}

the patients was $64.3 \pm 11.1$ years. Early pain was present in 55 patients and prolonged pain in 26 patients (Table 1). A comparison of patients' clinical and procedural characteristics according to early pain is shown in Table 2 . Male operator ratio was significantly higher in pain positive group than pain negative group $(67.3 \%$ vs. $37.8 \%$, $p=0.003$, respectively), and inexperienced operator ratio was also higher in pain positive group than pain negative one $(47.3 \%$ vs. $17.8 \%, p=0.002$, respectively). Patients' characteristics like age, gender, weight, height, BMI, hypertension, diabetes, hyperlipidemia, and active smoking were similar between the groups. Also, procedure-related factors including radial artery access time, fluoroscopy time, type of intervention (CAG or $\mathrm{PCl}$ ), intervention route (right or left radial), post-procedural radial occlusion, and the hematoma was not significantly different between the groups.

The comparison of patients' clinical and procedural characteristics according to prolonged pain is shown in Table 3. Inexperienced operator ratio was significantly higher in pain positive group than pain negative group ( $57.7 \%$ vs. $25.7 \%, p=0.003$; respectively). The patients with prolonged pain were younger compared to pain negative ones (56.2 \pm 13.2 vs. $61.8 \pm 9.9, p=0.027$; respectively). Patients' characteristics like gender, weight, height, BMI, hypertension, diabetes, hyperlipidemia, and active smoking were similar in the groups. Univariate and multivariate logistic regression analysis to predict pain after TRCA is shown in Table 4. The independent predictors of early pain after TRCA were male operator $(p=0.004$, $\mathrm{OR}=3.386,95 \% \mathrm{Cl}: 1.484-7.725)$, and inexperienced operator $(p=0.003, \mathrm{OR}=4.147,95 \% \mathrm{Cl}: 1.637-10.506)$. On the other hand, the younger age of patients $(p=0.032$, $\mathrm{OR}=0.955,95 \% \mathrm{Cl}: 0.915-0.966)$, and inexperienced operator $(p=0.004, \mathrm{OR}=3.947,95 \% \mathrm{Cl}$ : $1.547-10.047)$, were the independent predictors of prolonged pain after TRCA.

\section{Discussion}

In this study, we examined the pain that occurs in patients who underwent TRCA. We found that the gender and experience of the operator were independent factors related to post-procedural early pain. Also, the age of the patient and experience of the operator were independent factors related to prolonged pain; to the best of our knowledge, this is the first study in the literature about the pain after radial coronary angiography.

Transradial access is considered to be a safe and effective technique for coronary interventions, which favored over femoral access in clinical practice. ${ }^{14}$ TRCA has many advantages to transfemoral coronary angiography, such as less bleeding complications, more patient comfort, early ambulation, and short hospital stay. ${ }^{15-17}$ Also, it has

\begin{tabular}{l|l|l|l|}
\hline \multicolumn{5}{l}{ Table 2 - Comparison of patients' clinical and procedural characteristics according to the early pain } & \\
\hline & Pain $(+)(\mathbf{n}=55)$ & Pain $(-)(\mathbf{n}=45)$ & $p$-value \\
\hline Male, $n$ & $32(58.2 \%)$ & $33(73.3 \%)$ & 0.114 \\
\hline Age, years & $58.7 \pm 11.1$ & $62.4 \pm 10.9$ & 0.096 \\
\hline Height, $\mathrm{cm}$ & $166.3 \pm 8.8$ & $167.8 \pm 6.5$ & 0.068 \\
\hline Weight, $\mathrm{kg}$ & $81.1 \pm 11.7$ & $84.4 \pm 12.5$ & 0.182 \\
\hline BMl, $\mathrm{kg} / \mathrm{m}^{2}$ & $29.6 \pm 3.5$ & $29.6 \pm 4.31$ & 0.968 \\
\hline Hypertension, $\mathrm{n}(\%)$ & $31(56.4 \%)$ & $27(60 \%)$ & 0.714 \\
\hline Diabetes, $\mathrm{n}(\%)$ & $20(36.4 \%)$ & $19(42.2 \%)$ & 0.550 \\
\hline Hyperlipidemia, $\mathrm{n}(\%)$ & $31(56.4 \%)$ & $24(53.3 \%)$ & 0.762 \\
\hline Active smoking, $\mathrm{n}(\%)$ & $12(21.8 \%)$ & $9(20.0 \%)$ & 0.824 \\
\hline Access time, min & $3(5)$ & $3(5)$ & 0.857 \\
\hline Fluoroscopy time, min & $7(12)$ & $8(12)$ & 0.766 \\
\hline Only coronary angiography & $37(67.3 \%)$ & $30(66.7 \%)$ & 0.949 \\
\hline Left radial approach & $44(80.0 \%)$ & $30(66.7 \%)$ & 0.130 \\
\hline Male operator & $37(67.3 \%)$ & $17(37.8 \%)$ & 0.003 \\
\hline Inexperienced operator & $26(47.3 \%)$ & $8(17.8 \%)$ & 0.002 \\
\hline Post-procedural radial occlusion & $3(5.0 \%)$ & $1(2.0 \%)$ & 0.540 \\
\hline Hematoma & $1(1.8 \%)$ & 0 & - \\
\hline
\end{tabular}

Data are expressed as the median (interquartile range) for not normally distributed and mean \pm standard deviation or frequency for other factors. Significant difference if $p<0.05$. 
Table 3 - Comparison of patients' clinical and procedural characteristics according to prolonged pain

\begin{tabular}{|l|l|l|l|}
\hline & Pain $(+)(\mathbf{n}=\mathbf{2 6})$ & Pain $(-)(\mathbf{n}=74)$ & 0.599 \\
\hline Male, $n$ & $18(69.2 \%)$ & $47(63.3 \%)$ & 0.027 \\
\hline Age, years & $56.2 \pm 13.2$ & $61.8 \pm 9.9$ & 0.748 \\
\hline Height, $c m$ & $166.5 \pm 8.7$ & $167.0 \pm 7.8$ & 0.274 \\
\hline Weight, $\mathrm{kg}$ & $80.3 \pm 10.4$ & $83.3 \pm 12.6$ & 0.344 \\
\hline BMl, $\mathrm{kg} / \mathrm{m}^{2}$ & $29.0 \pm 3.3$ & $29.8 \pm 4.0$ & 0.177 \\
\hline Hypertension, $\mathrm{n}(\%)$ & $18(69.2 \%)$ & $40(54.1 \%)$ & 0.596 \\
\hline Diabetes, $\mathrm{n}(\%)$ & $9(34.5 \%)$ & $23(31.1 \%)$ & 0.177 \\
\hline Hyperlipidemia, $\mathrm{n}(\%)$ & $15(57.7 \%)$ & $40(54.1 \%)$ & 0.389 \\
\hline Active smoking, $\mathrm{n}(\%)$ & $7(26.9 \%)$ & $14(18.9 \%)$ & 0.452 \\
\hline Access time, min & $3(5)$ & $3(5)$ & 0.351 \\
\hline Fluoroscopy time, min & $7(12)$ & $8(12)$ & 0.444 \\
\hline Only coronary angiography & $19(73.1 \%)$ & $48(64.9 \%)$ & 0.360 \\
\hline Left radial approach & $21(80.8 \%)$ & $53(71.6 \%)$ & 0.661 \\
\hline Male operator & $15(57.3 \%)$ & $39(52.7 \%)$ & 0.003 \\
\hline Inexperienced operator & $15(57.7 \%)$ & $19(25.7 \%)$ & $1(1.3 \%)$ \\
\hline Post-procedural radial occlusion & $2(7.6 \%)$ & 0 & - \\
\hline Hematoma & $1(3.8 \%)$ & & - \\
\hline
\end{tabular}

Data are expressed as the median (interquartile range) for not normally distributed and mean \pm standard deviation or frequency for other factors. Significant difference if $p<0.05$.

Table 4 - Univariate and multivariate logistic regression analysis to predict pain after transradial coronary angiography

Univariate

Independent predictor of pain after two hours

\begin{tabular}{l|l|l|l|l|l|l|} 
& OR & Cl 95\% & $p$-value & OR & Cl 95\% & $p$-value \\
\hline Male operator & 3.386 & $1.484-7.725$ & 0.004 & 2.794 & $1.141-6.846$ & 0.025 \\
\hline Inexperienced operator & 4.147 & $1.637-10.506$ & 0.003 & 5.992 & $2.028-17.699$ & 0.001 \\
\hline Independent predictor of pain at one month & & & & & $0.908-0.995$ & 0.029 \\
\hline Age & 0.955 & $0.915-0.996$ & 0.032 & 0.950 & $1.884-16.245$ & 0.002 \\
\hline Inexperienced operator & 3.947 & $1.547-10.047$ & 0.004 & 5.533 &
\end{tabular}

substantial superiority in achieving local hemostasis due to its smaller vessel diameter and superficial localization. ${ }^{18}$ Therefore it has become the preferred route, especially in aggressive anticoagulation and antiplatelet treatment conditions. ${ }^{14}$ On the other hand, radial artery spasm, radial artery thrombosis, and hematoma are among the common complications of TRCA. ${ }^{19}$ Other rare complications of radial artery cannulation include dissection, pseudoaneurysm formation, infection, and perforation. ${ }^{19}$ Studies regarding pain during coronary angiography are commonly associated with analgesics and anesthetic techniques. ${ }^{9,10}$ Radial artery spasm has been extensively researched and is usually associated with procedure difficulty and procedure failure, and the incidence is around 4-20\%. . $^{2021}$ Until now, an optimal vasodilator cocktail has not been identified, the most used cocktail is the combination of nitroglycerin and heparin. ${ }^{22}$ The patients with radial spasm were excluded from the study.
We found that more than half of our patients suffered from pain in the early phase after TRCA, and this ratio dropped to 26 percent after a one-month follow-up. This prolonged pain rate was relatively high. Pain after TRCA could be explained by various factors. First of all, the patient's pain sensation is subjective and the psychological side should not be forgotten. Indeed, emotional episodes from minimally invasive cardiac procedures can lead to severe complications such as cardiomyopathy and arrhythmias. ${ }^{23}$ In our institution, 6F sheaths and catheters are generally used for radial procedures. We only use hydrophilic wires in very demanding situations. In the assessment of pain after the second hour, we found that TRCA performed by inexperienced operators caused more pain. We speculate that multiple puncture attempts could damage the artery and causing the initiation of the arteritis. Additionally, increased catheter maneuvers may result in subclinical spasm and dissections of the radial artery. 
The other independent predictor of pain in the second hour was the gender of the operator. Interestingly, we found that the procedures performed by male operators were more painful. According to a recent study, female surgeons have more positive outcomes compared to males in elective cases. ${ }^{24}$ Although the mechanism is not fully understood, this may be explained by the fact that female doctors are more compliant with guidelines and patient-based therapies. Additionally, a more collaborative approach of female doctors with patients may contribute a positive effect to this situation. ${ }^{24}$ In another study, it was determined that the basal surgical abilities of female medical students were superior to males. ${ }^{25}$ In our study, we thought that female operators' approach was more sensitive than male operators. Further, closer communication during the procedure between female operators and the patients may result in less pain.

In the evaluation of the patients at post-procedure first month, we found that TRCA performed by inexperienced operators caused more pain. We also found that younger patients experienced more pain than older patients. It has been shown that pain sensitivity decreases with increasing age. ${ }^{26}$ Similarly, Hensey et al. found that younger patients experienced more pain with the procedure in their study regarding the relationship between procedural pain and radial artery anatomy. ${ }^{12}$ There was no significant difference between the groups in terms of radial artery thrombosis, procedure-related factors, and patients' anthropometric measurements. Therefore, we speculate that these factors do not affect post-TRCA pain.

\section{Conclusion}

In conclusion, prolonged pain is not uncommon after transradial coronary angiography. We found that patient's age, operator gender and experience were leading factors associated with pain following TRCA.

\section{Study limitation}

This study should be evaluated in the light of some limitations. First, it is not a large sample-sized study. Secondly, we did not assess the anatomic variance of the radial artery that could cause pain. The rate of pain was relatively high that might be due to the catheter and sheath size. Finally, there were more than ten operators who performed procedures with varying degrees of experience.

\section{Conflict of interest}

None.

\section{Funding}

None.

\section{References}

1. Cooper CJ, El-Shiekh RA, Cohen DJ, et al. Effect of transradial access on quality of life and cost of cardiac catheterization: A randomized comparison. Am Heart J 1999;138(3 Pt 1):430436.
2. Mann T, Cubeddu G, Bowen J, et al. Stenting in acute coronary syndromes: a comparison of radial versus femoral access sites. J Am Coll Cardiol 1998;32:572-576.

3. Garcia-Blas S, Mainar L, Sanchis J, Nunez J. Complex left main coronary stent restenosis treated through radial approach using a sheathless catheter. Rev Port Cardiol 2016;35:543e1-543e5.

4. Dangoisse V, Guedes A, Gabriel L, et al. Full conversion from transfemoral to transradial approach for percutaneous coronary interventions results in a similar success rate and a rapid reduction of in-hospital cardiac and vascular major events. Eurolntervention 2013;9:345-352.

5. Jolly SS, Yusuf S, Cairns J, et al. Radial versus femoral access for coronary angiography and intervention in patients with acute coronary syndromes (RIVAL): a randomised, parallel group, multicentre trial. Lancet 2011;377:1409-1420.

6. Giannopoulos G, Raisakis K, Synetos A, et al. A predictive score of radial artery spasm in patients undergoing transradial percutaneous coronary intervention. Int J Cardiol 2015;188:76-80.

7. Desbiens NA, Wu AW, Broste SK, et al. Pain and satisfaction with pain control in seriously ill hospitalized adults: findings from the SUPPORT research investigations. For the SUPPORT investigators. Study to Understand Prognoses and Preferences for Outcomes and Risks of Treatment. Crit Care Med 1996;24:1953-1961.

8. Dai Y, Li C, Zhang F, et al. Safety and Efficacy of Percutaneous Coronary Intervention via Transradial Versus Transfemoral Approach in Bypass Grafts. Angiology 2018;69:136-142.

9. Kim JY, Yoon J, Yoo BS, et al. The effect of a eutectic mixture of local anesthetic cream on wrist pain during transradial coronary procedures. J Invasive Cardiol 2007;19:6-9.

10. Ruiz-Salmeron RJ, Mora R, Masotti M, Betriu A. Assessment of the efficacy of phentolamine to prevent radial artery spasm during cardiac catheterization procedures: a randomized study comparing phentolamine vs. verapamil. Catheter Cardiovasc Interv 2005;66:192-198.

11. Ruiz-Salmeron RJ, Mora R, et al. Radial artery spasm in transradial cardiac catheterization. Assessment of factors related to its occurrence and of its consequences during follow-up. Rev Esp Cardiol 2005;58;504-511.

12. Hensey M, Cronin E, Owens P. Influence of radial anatomy on pain experienced during transradial coronary angiography. Int J Cardiol 2016;218:202-205.

13. Hawker GA, Mian S, Kendzerska T, French M. Measures of adult pain: Visual Analog Scale for Pain (VAS Pain), Numeric Rating Scale for Pain (NRS Pain), McGill Pain Questionnaire (MPQ), Short-Form McGill Pain Questionnaire (SF-MPQ), Chronic Pain Grade Scale (CPGS), Short Form-36 Bodily Pain Scale (SF-36 BPS), and Measure of Intermittent and Constant Osteoarthritis Pain (ICOAP). Arthritis Care Res 2011;63(Suppl. 11):S240-S252.

14. Deveci B, Ozeke O, Gul M, et al. Impact of the radial versus femoral access for primary percutaneous intervention on smoking cessation rates: A paradoxus between the health related quality of life and smoking quitting? Cor Vasa 2018;60:e381-e386.

15. Amoroso G, Kiemeneij F. Transradial access for primary percutaneous coronary intervention: the next standard of care? Heart 2010;96:1341-1344.

16. Siudak Z, Zawislak B, Dziewierz A,et al. Transradial approach in patients with ST- elevation myocardial infarction treated with abciximab results in fewer bleeding complications: data from EUROTRANSFER registry. Coron Artery Dis 2010;21:292-297.

17. Hahalis G, Tsigkas G, Kakkos S,et al. Vascular Complications Following Transradial and Transulnar Coronary Angiography in 1600 Consecutive Patients. Angiology 2016;67:438-443.

18. Kubiak G, Traczewska, M. Percutaneous coronary interventions via the radial approach - Mandatory or elective in the current circumstances - A Polish perspective. 
Cor Vasa 2013;55:e515-e519.

19. Coghill EM, JohnsonT, Morris RE, et al. Radial artery access site complications during cardiac procedures, clinical implications and potential solutions: The role of nitric oxide. World J Cardiol 2020;12:26-34.

20. Coppola J, Patel T, Kwan T,et al. Nitroglycerin, nitroprusside, or both, in preventing radial artery spasm during transradial artery catheterization. J Invasive Cardiol 2006;18:155-158.

21. Varenne O, Jegou A, Cohen R, et al. Prevention of arterial spasm during percutaneous coronary interventions through radial artery: the SPASM study. Catheter Cardiovasc Interv 2006;68:231-235.

22. Bi X, Wang Q, Liu D, et al. Is the Complication Rate of Ulnar and Radial Approaches for Coronary Artery Intervention the Same? Angiology 2017;68:919-925.
23. Casale M, Quattrocchi S, Bitto R, Dattilo G. Cardiac implantable devices and takotsubo syndrome. A rare but potential eventuality. Cor Vasa 2018;60:e500-e502.

24. Wallis CJ, Ravi B, Coburn N, et al. Satkunasivam R. Comparison of postoperative outcomes among patients treated by male and female surgeons: a population based matched cohort study. BMJ 2017;359:j4366.

25. Lou Z, Yan FH, Zhao ZQ, et al. The Sex Difference in Basic Surgical Skills Learning: A Comparative Study. J Surg Educ 2016;73:902-905.

26. Lautenbacher S, Peters JH, Heesen M, et al. Age changes in pain perception: A systematic-review and meta-analysis of age effects on pain and tolerance thresholds. Neurosci Biobehav Rev 2017;75:104-113. 